\title{
EFFECT OF MINERAL ADMIXTURES ON CHARACTERISTICS OF HIGH STRENGTH CONCRETE
}

\author{
Ashfi Rahman ${ }^{1}$, Harjinder Singh ${ }^{2}$ \\ ${ }^{1} M E$ Structures, PEC University of technology, Chandigarh, India \\ ${ }^{2}$ ME Highways, PEC University of technology, Chandigarh, India
}

\begin{abstract}
There is great need to conserve all the natural resources. The various steps to be adopted in the direction that includes minimization of production of energy consuming materials and heavy utilization of industrial by-products. High strength concrete can be produce using such materials like fly ash, slag and silica fumes. In many countries, these materials are already used in manufacturing of concrete. Some of these material can be used as replacement for cement. Ultimately it results in the reduction of the cost manufacturing of concrete and reduces environmental pollution. To study the effect of mineral admixtures such as fly ash, slag and silica fume on mechanical properties of high strength concrete under the uniaxial compression and split tensile, experimental studies have been conducted. The cement was replaced by 5\%,10\%, 15\% and $20 \%$ with fly ash and slag respectively. The compressive strength and split tensile test were conducted on concrete specimen with different percentages of fly ash and slag at age of 7 days, 28 days and 56 days. This study shows that materials used in this experiment are suitable for HSC.
\end{abstract}

Keywords: environmental pollution, fly ash, slag and silica fumes

\section{INTRODUCTION}

Concrete plays an important role in the construction industry. In the last few decades, many researches have been carried on the properties of concrete by using waste materials and by products. Thus, it has emphasized the use of waste materials and by products like fly ash and blast furnace slag as a partial replacement of cement in the manufacturing of concrete.

The development of prestressed concrete in the construction industry has generated interest in the high strength concrete (HSC). With the successive increase in compressive strength of concrete, the definition of high strength concrete has kept on changing. ACI committee 363 has defined HSC as "The concrete with specified compressive strength equal to or greater than 40 Mpa." The most common supplementary cement materials (SCMs) are fly ash, blast furnace slag and silica fume.

Fly ash, also known as flue-ash, is one of the residues generated in combustion, and comprises the fine particles that rise with the flue gases. Ash that does not rise is called bottom ash. In an industrial context, fly ash usually refers to ash produced during combustion of coal. When the cement in concrete is partially replaced by fly ash, then the concrete formed is known as fly ash concrete.

Blast-furnace slag is obtained by quenching molten iron slag (a by-product of iron and steel-making) from a blast furnace in water or steam, to produce a glassy, granular product that is then dried and ground into a fine powder.

\section{OBJECTIVES}

The primary objective of the work is to experimentally study the effect of the replacement of cement with fly ash, blast furnace slag and silica fume on the characteristic of HSC and to obtain the optimum percentage of replacement of cement in concrete.

The main objective of the study are as under :-

1. To study the effect of mineral admixture on workability of high strength concrete.

2. To study the effect of mineral admixture on compressive strength of high strength concrete at the age of 7, 28 and 56 days.

3. To study the effect of mineral admixture on split tensile strength of high strength concrete at the age of 7,28 and 56 days.

\section{LITERATURE REVIEW}

Hindly et al has reported that when silica fume is mixed with OPC in low water-cement ratios, the microstructure of such mixture has mainly crystalline hydrates forming a denser matrix of low porosity. As the content of the silica fume is increased in the concrete, major part of calcium hydroxide is transformed into calcium silicate hydrates while leftover calcium hydroxide has the tendency to the form smaller crystals compared in the OPC paste.

Zhang and Malhotra studied the split tensile strength, flexural strength of normal concrete, rice husk ash (RHA) concrete and silica fume concrete. The added 10 percent of RHA and silica fume by weight of cement and have reported that $\mathrm{MPa}, 3.5 \mathrm{MPa}$ and $2.8 \mathrm{MPa}$ respectively, where as flexural strength is 6.3 Mpa, 7.0 Mpa and 7.0 Mpa for normal, RHA and silica fume concrete respectively. 
Earlier, fly ash was looked upon as a raw material for the manufacture of cement. Detroit Edison Company and Cleaveland Electric illuminating Company were among the reporters of fly ash.

In 1937, the first systematic work on the use of fly ash in concrete was reported by David and his co-workers at university of California. He studied different properties of fly ash.

Leanard and Philip reported use of excess fly ash than the amount of cement and found that the resulting concrete had increased ultimate strength and reduced drying shrinkage and improved workability.

Reshi published a method of proportioning fly ash concrete mixes for getting the same strength as of plain concrete after 28 days.

Research at C.B.R.I., Bihar and Smrd Madras has shown that the fly ash with higher coal content was more corrosive and concrete mix having more than $30 \%$ replacement of cement by fly ash had higher corrosive properties.

\section{MATERIALS}

This work consists of casting, curing and testing of concrete specimen nwith varying percentages of fly ash, slag and silica fume at different ages.

\subsection{Portland Cement}

OPC of 53 grade was used for making concrete, it was fresh and free from lumps.

\subsection{Coarse Aggregates}

Crushed stone aggregates were used. The maximum size of the aggregate is $10 \mathrm{~mm}$ used in the experiment. The coarse aggregates were tested as per IS: 2386-1963.

The partical size gradation was obtained by sieve analysis.

\subsection{Fine Aggregates}

The fine aggregates used in the experiment were collected from ghaggher river. It was coarse sand brown in colour. Specific gravity of fine aggregates was 2.62. The sand was examined as per IS: 383-1970.

\subsection{Fly Ash}

The fly ash used in present work was obtained from ropar thermal power plant. The fly ash which was used falls under class F category.

\section{EXPERIMENTAL PROCEDURE}

\subsection{Mix Proprtioning and Casting}

In this study, mix was prepared with and without fly ash, slag and silica fume. The mix without fly ash, slag and silica fume is termed as control mix. The 26 mixes were prepared by varying percentages of fly ash and slag as a part of replacement of cement. In all, 150 specimens were casted, out of which 75 cubes specimens were tested for compressive test and 75 cylinders were casted for both split tensile strength test and modulus of elasticity test and 25 beams were casted for dry shrinkage test.

Table.1 Mix design of M-65 grade concrete

\begin{tabular}{|l|l|l|}
\hline Ingredients & $\begin{array}{l}\text { Dry } \\
\text { aggregates } \\
\left(\mathbf{K g} / \mathbf{m}^{3}\right)\end{array}$ & $\begin{array}{l}\text { Moist } \\
\text { aggregates } \\
\left(\mathbf{K g} / \mathbf{m}^{3}\right)\end{array}$ \\
\hline Cement & 495 & 495 \\
\hline Water & 149 & 136 \\
\hline $\begin{array}{l}\text { Fine } \\
\text { aggregates }\end{array}$ & 535 & 520 \\
\hline $\begin{array}{l}\text { Coarse } \\
\text { aggregates }\end{array}$ & 1248 & 1235 \\
\hline
\end{tabular}

Table 2 Mix designation and mix proportion of M-65 grade concrete

\begin{tabular}{|c|c|c|c|c|c|c|c|c|c|c|c|c|}
\hline \multirow{2}{*}{$\begin{array}{l}\text { Mix } \\
\text { Designati } \\
\text {-on }\end{array}$} & \multirow{2}{*}{$\begin{array}{l}\text { w/(c+p) } \\
\text { Ratio }\end{array}$} & \multicolumn{2}{|c|}{ Cement } & \multicolumn{2}{|c|}{ Fly Ash } & \multicolumn{2}{|c|}{$\begin{array}{l}\text { Silica } \\
\text { Fume }\end{array}$} & \multicolumn{2}{|c|}{ Slag } & \multirow{2}{*}{$\begin{array}{l}\text { Fine } \\
\text { Aggre- } \\
\text { gate }\end{array}$} & \multirow{2}{*}{$\begin{array}{l}\text { Coarse } \\
\text { Aggreg } \\
\text {-ate }\end{array}$} & \multirow{2}{*}{$\begin{array}{l}\text { Superplas } \\
\text {-ticizer } \\
(1 \% \text { by } \\
\text { wt. of } \\
\text { cement })\end{array}$} \\
\hline & & $\begin{array}{l}\% \\
\text { age }\end{array}$ & $\begin{array}{l}\text { Wt. } \\
\text { (Kg) }\end{array}$ & $\begin{array}{l}\% \\
\text { age }\end{array}$ & $\begin{array}{l}\text { Wt. } \\
\text { (Kg) }\end{array}$ & $\begin{array}{l}\% \\
\text { age }\end{array}$ & \begin{tabular}{|l|} 
Wt. \\
(Kg)
\end{tabular} & $\begin{array}{l}\% \\
\text { age }\end{array}$ & $\begin{array}{l}\text { Wt. } \\
\text { (Kg) }\end{array}$ & & & \\
\hline A0 & 0.3 & 100 & 495 & \multirow{6}{*}{0} & 0 & 5 & 24.75 & 0 & 0 & 535 & 1248 & 5.13 \\
\hline A1 & 0.3 & 95 & 470.0 & & 0 & 5 & 24.75 & 0 & 0 & 535 & 1248 & 5.13 \\
\hline A2 & 0.3 & 90 & 445.5 & & 0 & 5 & 24.75 & 5 & 24.75 & 535 & 1248 & 5.13 \\
\hline $\mathbf{A 3}$ & 0.3 & 85 & 420.5 & & 0 & 5 & 24.75 & 10 & 49.50 & 535 & 1248 & 5.13 \\
\hline A4 & 0.3 & 80 & 394.0 & & 0 & 5 & 24.75 & 15 & 74.25 & 535 & 1248 & 5.13 \\
\hline A5 & 0.3 & 75 & 348.5 & & 0 & 5 & 24.75 & 20 & 102.6 & 535 & 1248 & 5.13 \\
\hline A6 & 0.3 & 90 & 445.5 & \multirow{5}{*}{5} & 24.7 & 5 & 24.75 & 0 & 0 & 535 & 1248 & 5.13 \\
\hline A7 & 0.3 & 85 & 436.0 & & 24.7 & 5 & 24.75 & 5 & 24.75 & 535 & 1248 & 5.13 \\
\hline A8 & 0.3 & 80 & 420.5 & & 24.7 & 5 & 24.75 & 10 & 49.5 & 535 & 1248 & 5.13 \\
\hline A9 & 0.3 & 75 & 394.0 & & 24.7 & 5 & 24.75 & 15 & 74.25 & 535 & 1248 & 5.13 \\
\hline A10 & 0.3 & 70 & 348.5 & & 24.7 & 5 & 24.75 & 20 & 99.0 & 535 & 1248 & 5.13 \\
\hline A11 & 0.3 & 85 & 420.5 & & 49.5 & 5 & 24.75 & 0 & 0 & 535 & 1248 & 5.13 \\
\hline A12 & 0.3 & 80 & 394.0 & & 49.5 & 5 & 24.75 & 5 & 24.75 & 535 & 1248 & 5.13 \\
\hline
\end{tabular}




\begin{tabular}{|c|c|c|c|c|c|c|c|c|c|c|c|c|}
\hline A13 & 0.3 & 75 & 348.5 & \multirow[t]{3}{*}{10} & 49.5 & 5 & 24.75 & 10 & 49.5 & 535 & 1248 & 5.13 \\
\hline A14 & 0.3 & 70 & 323.7 & & 49.5 & 5 & 24.75 & 15 & 74.25 & 535 & 1248 & 5.13 \\
\hline A15 & 0.3 & 65 & 299.0 & & 49.5 & 5 & 24.75 & 20 & 99.0 & 535 & 1248 & 5.13 \\
\hline A16 & 0.3 & 80 & 394.0 & \multirow{5}{*}{15} & 74.2 & 5 & 24.75 & 0 & 0 & 535 & 1248 & 5.13 \\
\hline A17 & 0.3 & 75 & 348.5 & & 74.2 & 5 & 24.75 & 5 & 24.75 & 535 & 1248 & 5.13 \\
\hline A18 & 0.3 & 70 & 323.5 & & 74.2 & 5 & 24.75 & 10 & 49.50 & 535 & 1248 & 5.13 \\
\hline A19 & 0.3 & 65 & 299.0 & & 74.2 & 5 & 24.75 & 15 & 74.25 & 535 & 1248 & 5.13 \\
\hline A20 & 0.3 & 60 & 274.2 & & 74.2 & 5 & 24.75 & 20 & 99.0 & 535 & 1248 & 5.13 \\
\hline A21 & 0.3 & 75 & 348.5 & \multirow{5}{*}{20} & 99.0 & 5 & 24.75 & 0 & 0 & 535 & 1248 & 5.13 \\
\hline A22 & 0.3 & 70 & 323.7 & & 99.0 & 5 & 24.75 & 5 & 24.75 & 535 & 1248 & 5.13 \\
\hline A23 & 0.3 & 65 & 299.0 & & 99.0 & 5 & 24.75 & 10 & 49.50 & 535 & 1248 & 5.13 \\
\hline A24 & 0.3 & 60 & 274.2 & & 99.0 & 5 & 24.75 & 15 & 74.25 & 535 & 1248 & 5.13 \\
\hline A25 & 0.3 & 55 & 249.5 & & 99.0 & 5 & 24.75 & 20 & 99.0 & 535 & 1248 & 5.13 \\
\hline
\end{tabular}

\subsection{Testing And Results}

\subsubsection{Workability}

The workability of all the cube that were prepared and discussed in above tables were tested by compaction factor test. The range of the workability lies between 0.86 to 0.93 for different concrete mixes.

Table 3.1 Workabilty with the varying percentage of slag and fly ash

\begin{tabular}{|l|l|l|l|l|l|}
\hline \%age Fly ash & 0\% Slag & $\mathbf{5 \%}$ Slag & $\mathbf{1 0 \%}$ slag & $\mathbf{1 5 \%}$ slag & $\mathbf{2 0 \%}$ slag \\
\hline 0 & 0.867 & 0.860 & 0.873 & 0.883 & 0.885 \\
\hline 5 & 0.871 & 0.875 & 0.882 & 0.892 & 0.903 \\
\hline 10 & 0.860 & 0.883 & 0.891 & 0.902 & 0.911 \\
\hline 15 & 0.885 & 0.890 & 0.902 & 0.908 & 0.890 \\
\hline 20 & 0.900 & 0.912 & 0.929 & 0.910 & 0.870 \\
\hline
\end{tabular}

\subsubsection{Split Tensile Strength Test}

After the testing, it was concluded that there is slight increase in the value of split tensile strength of 7, 28 and 56 days when fly ash slag and silica fume is added to the mix as compare to the control mix at lower replacement levels.

Table 3.2: Test results for Split tensile strength test

\begin{tabular}{|c|c|c|c|c|c|c|}
\hline \multirow[t]{2}{*}{ Mixes } & \multirow[t]{2}{*}{ \% Fly ash } & \multirow[t]{2}{*}{ \% Slag } & \multirow[t]{2}{*}{$\%$ Silica fume } & \multicolumn{3}{|c|}{ Split tensile Strength (Mpa) } \\
\hline & & & & 7 Days & 28 Days & 56 Days \\
\hline A0 & 0 & 0 & 0 & 5.02 & 7.36 & 8.03 \\
\hline A1 & \multirow{5}{*}{0} & 0 & \multirow{5}{*}{5} & 5.62 & 7.92 & 8.45 \\
\hline A2 & & 5 & & 5.52 & 7.65 & 8.32 \\
\hline$\overline{\mathrm{A3}}$ & & 10 & & 5.43 & 7.60 & 8.30 \\
\hline A4 & & 15 & & 5.32 & 7.40 & 8.10 \\
\hline A5 & & 20 & & 5.25 & 7.22 & 7.89 \\
\hline A6 & \multirow{5}{*}{5} & 0 & \multirow{5}{*}{5} & 5.40 & 7.87 & 8.41 \\
\hline A7 & & 5 & & 5.32 & 7.80 & 8.32 \\
\hline $\mathbf{A 8}$ & & 10 & & 5.10 & 7.40 & 8.30 \\
\hline A9 & & 15 & & 4.88 & 7.38 & 8.10 \\
\hline $\mathbf{A 1 0}$ & & 20 & & 4.75 & 7.34 & 7.82 \\
\hline A11 & & 0 & & 5.21 & 7.92 & 8.39 \\
\hline A12 & & 5 & & 5.10 & 7.46 & 8.34 \\
\hline
\end{tabular}




\begin{tabular}{|c|c|c|c|c|c|c|}
\hline A13 & \multirow{3}{*}{10} & 10 & \multirow{3}{*}{5} & 5.02 & 7.41 & 8.02 \\
\hline A14 & & 15 & & 4.98 & 7.23 & 7.68 \\
\hline A15 & & 20 & & 4.97 & 7.04 & 7.62 \\
\hline A16 & \multirow{5}{*}{15} & 0 & \multirow{5}{*}{5} & 5.02 & 7.40 & 8.22 \\
\hline A17 & & 5 & & 4.92 & 7.23 & 8.02 \\
\hline A18 & & 10 & & 4.82 & 7.17 & 7.82 \\
\hline A19 & & 15 & & 4.62 & 7.10 & 7.65 \\
\hline $\mathbf{A 2 0}$ & & 20 & & 4.36 & 6.91 & 7.58 \\
\hline A21 & \multirow{5}{*}{20} & 0 & \multirow{5}{*}{5} & 4.94 & 7.35 & 8.04 \\
\hline A22 & & 5 & & 4.85 & 7.23 & 7.69 \\
\hline $\mathbf{A 2 3}$ & & 10 & & 4.68 & 7.04 & 7.48 \\
\hline A24 & & 15 & & 4.39 & 6.89 & 7.41 \\
\hline A25 & & 20 & & 4.25 & 6.76 & 7.31 \\
\hline
\end{tabular}

\subsubsection{Compressive Strength}

The cube of size $150 \mathrm{~mm}$ X $150 \mathrm{~mm}$ X $150 \mathrm{~mm}$ were casted and cured for 7,28 and 56 days and then tested immediately after taking off from water. The specimens were tested on 200 tonne capacity universal testing machine. The load at which specimen fails were noted down and compressive strength was found out.

Table 3.3: Test results for Compressive strength test

\begin{tabular}{|c|c|c|c|c|c|c|}
\hline \multirow[t]{2}{*}{ Mixes } & \multirow[t]{2}{*}{ \% Fly ash } & \multirow[t]{2}{*}{ \% Slag } & \multirow{2}{*}{$\begin{array}{l}\text { \% Silica } \\
\text { fume }\end{array}$} & \multicolumn{3}{|c|}{ Compressive Strength (Mpa) } \\
\hline & & & & 7 Days & 28 Days & 56 Days \\
\hline A0 & 0 & 0 & 0 & 50.24 & 73.90 & 79.20 \\
\hline A1 & \multirow{5}{*}{0} & 0 & \multirow{5}{*}{5} & 56.22 & 78.96 & 85.30 \\
\hline $\mathbf{A 2}$ & & 5 & & 55.30 & 77.20 & 83.40 \\
\hline $\mathbf{A 3}$ & & 10 & & 54.02 & 76.40 & 81.80 \\
\hline A4 & & 15 & & 53.05 & 75.20 & 80.20 \\
\hline A5 & & 20 & & 52.06 & 74.20 & 79.40 \\
\hline A6 & \multirow{5}{*}{5} & 0 & \multirow{5}{*}{5} & 54.20 & 78.46 & 84.20 \\
\hline A7 & & 5 & & 52.30 & 76.90 & 83.50 \\
\hline A8 & & 10 & & 50.80 & 75.60 & 81.60 \\
\hline A9 & & 15 & & 49.20 & 74.12 & 80.20 \\
\hline A10 & & 20 & & 48.60 & 73.45 & 80.02 \\
\hline A11 & \multirow{5}{*}{10} & 0 & \multirow{5}{*}{5} & 51.20 & 77.60 & 83.60 \\
\hline A12 & & 5 & & 50.20 & 75.80 & 82.01 \\
\hline $\mathbf{A 1 3}$ & & 10 & & 49.05 & 74.20 & 80.30 \\
\hline A14 & & 15 & & 48.40 & 72.10 & 78.10 \\
\hline A15 & & 20 & & 47.30 & 70.80 & 76.20 \\
\hline A16 & & 0 & & 50.20 & 75.60 & 82.10 \\
\hline A17 & & 5 & & 49.10 & 73.80 & 80.02 \\
\hline A18 & & 10 & & 48.30 & 72.40 & 78.10 \\
\hline
\end{tabular}




\begin{tabular}{|c|c|c|c|c|c|c|}
\hline A19 & 15 & 15 & 5 & 47.40 & 70.60 & 75.80 \\
\hline $\mathbf{A 2 0}$ & & 20 & & 46.30 & 69.30 & 74.10 \\
\hline $\mathbf{A 2 1}$ & \multirow{5}{*}{20} & 0 & \multirow{5}{*}{5} & 49.10 & 74.30 & 80.20 \\
\hline A22 & & 5 & & 48.20 & 72.60 & 78.10 \\
\hline A23 & & 10 & & 47.08 & 70.45 & 75.86 \\
\hline A24 & & 15 & & 46.23 & 69.73 & 74.30 \\
\hline A25 & & 20 & & 45.23 & 68.42 & 73.04 \\
\hline
\end{tabular}

\section{CONCLUSION}

The following conclusions can be drawn from the experimental investigation:-

1. The replacement materials i.e fly ash, blast furnace slag and silica fume are suitable for making high strength concrete.

2. It was also observed that addition of silica fume to concrete leads to improvement in compressive strength and split tensile strength of concrete at all ages.

3. The replacement of cement by fly ash and slag results in improving the workability upto a replacement level of $30 \%$.

4. It was concluded that fly ash an blast furnace slag concrete attatins low early ages strength as compared to normal concrete. But the rate of development of strength is more at later stages.

5. It was found that optimum level of replacement of cement by slag and fly ash is around $20 \%$ as the strength shown by slag and fly ash cement at the replacement level is nearly equal to strength shown without fly ash and blast furnace slag concrete at 28 days and 56 days.

\section{REFERENCES}

[1] ACI Committee 363, "State of art report on high strength concrete", ACI Journal, vol- 81, No.4,1984, pp366-411.

[2] ACI Committee 212, "Chemical admixtures for concrete", ACI materials journal, Vol-86, No.3, 1989, pp 297-337.

[3] ACI Committee 211, "Guide for selecting proportions for HSC with Portland cement and fly ash", ACI material journal vol-90, No.3. 1993, pp 273-283.

[4] ACI Committee, "High performance concrete: requirement for constituent materials and mix proportioning", ACI material joural, May-June 1996, pp 233-241.

[5] Hindy, E.E., Micro B.Omar, and Aitchin,P.S .," Drying shrinkage of ready mixed high performance concrete". ACI material journal Vol. 91 No.3, MayJune 1994, pp 300-305.

[6] IS:10262-1982, Recommended guidelines for concrete mix design, Bereau of Indian Standard, New Delhi- 1982.
[7] IS: 12269-1987,"Specification for 53 grade Ordinary Portland cement", Bereau of Indian Standard, New Delhi- 1999.

[8] IS: 516-1959 (reaffirmed 1999) "Methods of tests for strength of concrete". Bereau of Indian Standard, New Delhi- 1999.

[9] IS: 9103- 1999: Concrete AdmixturesSpecifications, Bereau of Indian Standard, New Delhi- 1999.

[10] IS: 456-2000: Code of practice-plain and reinforced concrete, Bereau of Indian Standard, New Delhi2000.

[11] Malhotra, V.M., Proceeding $1^{\text {st }}$ international conference on the use of Fly Ash, Slag, Silica fume and other material by product in concrete 1983.

[12] Reshi S.S and Garg, S.K., "Proportioning concrete containing fly ash", the IEI journal, 1964, vol.45.

[13] Zhang M.H and Malhotra, V.M., "Making concrete greener with Fly ash", Indian Conrete Journal, Oct 1999, pp 609-615. 